\title{
$\beta$-Receptor-stimulated and Cyclic Adenosine 3',5'-Monophosphate- mediated Taurine Release from LRM55 Glial Cells ${ }^{1}$
}

\author{
V. MADELIAN, ${ }^{* 2}$ D. L. MARTIN, ${ }^{*}$ R. LEPORE, $\ddagger$ M. PERRONE, $\ddagger$ AND W. SHAIN* \\ * Laboratory of Neurotoxicology and Nervous System Disorders, Wadsworth Center for Laboratories and Research, New York State \\ Department of Health, Albany, New York 12201 and $\ddagger$ Sterling Winthrop Research Institute, Rensselaer, New York 12144
}

\begin{abstract}
Adrenergic stimulation of LRM55 glial cells results in the release of the neuroactive amino acid taurine. The present study characterizes the receptors involved in taurine release and shows that taurine release is mediated by cyclic adenosine $3^{\prime}, 5^{\prime}$-monophosphate (cAMP).

$\beta$-Receptors in L.RM55 cells were first characterized by $\left[{ }^{125} \mathrm{I}\right]$ iodohydroxybenzylpindolol binding. Binding was stereospecific and saturable with time and ligand concentration. Kinetic analysis of equilibrium binding at $37^{\circ} \mathrm{C}$ revealed a single component of high affinity $\left(K_{\mathrm{m}}=113 \mathrm{pm} ; B_{\max }=52.1\right.$ $\pm 5.0 \mathrm{fmol} / \mathrm{mg}$ of protein).

The pharmacologies of the stimulation of cAMP accumulation and taurine release were similar. The agonists isoproterenol (IPR), epinephrine (E) and norepinephrine (NE) showed a rank order of potency characteristic of a $\beta$-adrenergic system (IPR $>E \geq N E$ ). The $\beta$-antagonists alprenolol and propranolol inhibited the IPR stimulation of both processes; the $\alpha$-antagonist phentolamine did not.

The dependence of taurine release on CAMP was further suggested by the similarity of the two time courses and was demonstrated by the stimulation of taurine release by the cAMP analogue dibutyryl cAMP.

Thus, one physiological response of glial cells to $\beta$-adrenergic stimulation is the release of taurine. Receptor-activated release of taurine from glia represents a previously undescribed neuronal-glial interaction by which glia may actively regulate neuronal excitability.
\end{abstract}

Glia represent more than $50 \%$ of the mass of the brain and may outnumber neurons by as much as 10:1 (Pope, 1978), yet relatively little is known about their physiological role in the central nervous system (CNS). Glia may provide directional and structural growth factors during development (Banker, 1980; Hatten and Liem, 1981; Denis-Donini et al., 1984), provide certain metabolites to neurons (Opler and Makman, 1972), help regulate the ionic environment of the extracellular space (Kuffler et al., 1966; Kufler, 1967), and inactivate certain neurotransmitters by accumulating them (Varon and Somjen, 1979, and references therein). Thus, glial cells are believed to be passive partners in nervous system physiology, either nurturing neurons with growth factors and/or metabolites or maintaining homeostatic conditions for neurons.

Received December 28, 1984; Revised June 3, 1985;

Accepted June 4, 1985

\footnotetext{
${ }^{1}$ We are grateful to Ms. Joyce White and Ms. Kathy Marczak for typing this manuscript.

${ }^{2}$ To whom correspondence should be addressed.
}

Specific receptors for a number of neurotransmitters have been identified on glial cells. The best studied of these has been the $\beta$ adrenergic receptor (see "Discussion"); however, muscarinic acetylcholine (Repke and Maderspach, 1982), serotonin (Tardy et al. 1982), glutamate (Bowman and Kimelberg, 1984), histamine (Hosli et al., 1984), and a variety of peptide receptors (Van Calker and Hamprecht, 1980; Perrone et al., 1983; Rougon et al., 1983) have also been described. More than one of these receptors have been studied as regulators of cyclic adenosine $3^{\prime}, 5^{\prime}$-monophosphate (cAMP). Although $\beta$-adrenergic stimulation of CAMP has been correlated with increased glycogenolysis in primary cultures of astrocytes (Opler and Makman, 1972) and induction of lactic dehydrogenase in a glial cell line (deVellis and Brooker, 1972), the physiolog ical consequences of such changes for glial cell function in the CNS are not well understood.

Glial cell function can be studied using primary cultures and continuous cell lines. The LRM55 glial cell line studied in our laboratory was obtained from a single cell clone (Martin and Shain, 1979) from an ethyl nitrosourea-induced rat spinal cord tumor (Morantz et al., 1978). This cell line exhibits a number of glial properties, including astrocytic morphology, high affinity transport of the amino acid neurotransmitters taurine and glutamate (Martin and Shain, 1979; Waniewski and Martin, 1983), nonexcitable membrane properties similar to those reported for glia (Seligmann et al, 1979), anion exchange and transport mechanisms (Wolpaw and Martin, 1982), the presence of glial fibrillary acidic protein (W. Shain, unpublished observation), and synthesis of a glial cell growth factor (Sakazaki ct al., 1982)

Recent studies with LRM55 glial cells demonstrated that the stimulation of adrenergic (Shain et al., 1983; Shain and Martin, 1984) and $\kappa$-opiate (Shain et al., 1984) receptors stimulate the specific release of the inhibitory neuroactive amino acid taurine.

The present study was undertaken to measure the binding kinetics and pharmacological properties of adrenergic receptors on LRM55 glial cells and to describe the relationship between receptor occupancy, intracellular CAMP accumulation, and release of taurine.

\section{Materials and Methods}

Chemicals. ( \pm )- $\left[{ }^{125} \mid\right]$ lodohydroxybenzylpindolol ([ $\left.{ }^{125}\right]$ ll IYP), [ ${ }^{3} \mid$ I]taurine, and radioimmunoassay kits for CAMP assays were purchased from New England Nuclear (Boston, MA). (-)-Propranolol and (+)-propranolol (PROP) were purchased from Ayerst Laboratories (Rouses Point, NY). Dibutyryl CAMP (db-cAMP), 8-bromo-cAMP (8-Br-cAMP), (-)-alprenolol (ALP), (-)-norepinephrine (NE), (-)-epinephrine (E), and (-) and (+)-isoproterenol (IPR) were purchased from Sigma Chemical Co. (St. Louis, MO). Phentolamine (PHENT) was purchased from Ciba-Geigy (Summit, NJ).

Cell preparation. LRM55 cells were grown to confluence at $37^{\circ} \mathrm{C}$ in a $5 \%$ $\mathrm{CO}_{2} / 95 \%$ air atmosphere, in $100 \mathrm{~mm}$ plastic Petri plates, in 24-well plastic trays, or on pieces of cell support film (Bellco, Vineland, $\mathrm{NJ}$ ) for measure- 


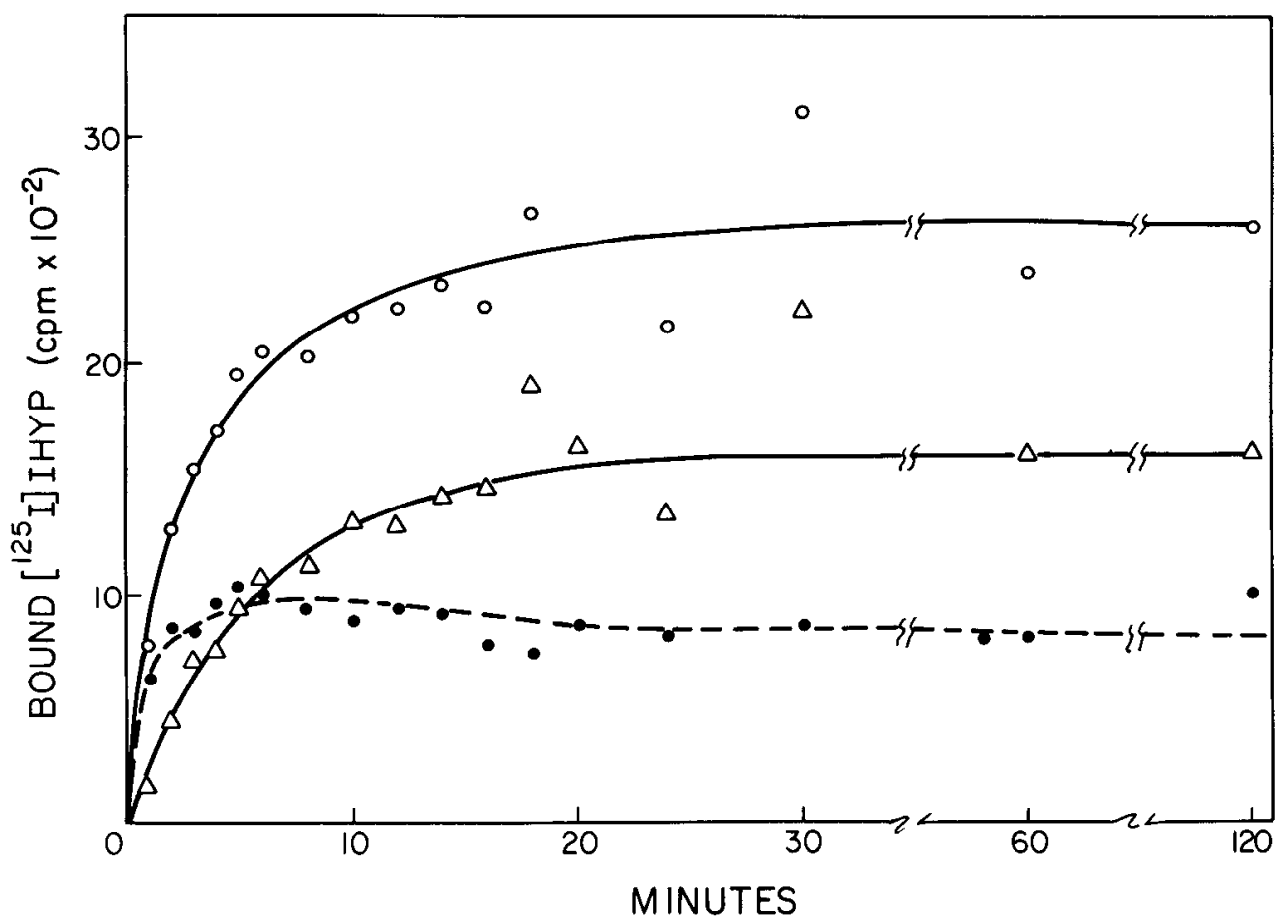

Figure 1. Time course of [ $\left.\left.{ }^{125}\right]\right] \mathrm{HYP}$ binding to LRM55 cells. Crude cell preparations ( $100 \mu \mathrm{g}$ of protein/tube) were incubated with $\left.20 \mathrm{PM}\left[{ }^{125}\right]\right] \mathrm{HYP}$ in the presence (O) or absence (O) of $10^{-6} \mathrm{M}(-)$-PROP for various times. The specifically bound $\left.\left[{ }^{125}\right]\right] \mathrm{HYP}(\triangle)$ is the difference between total and nonspecific binding.

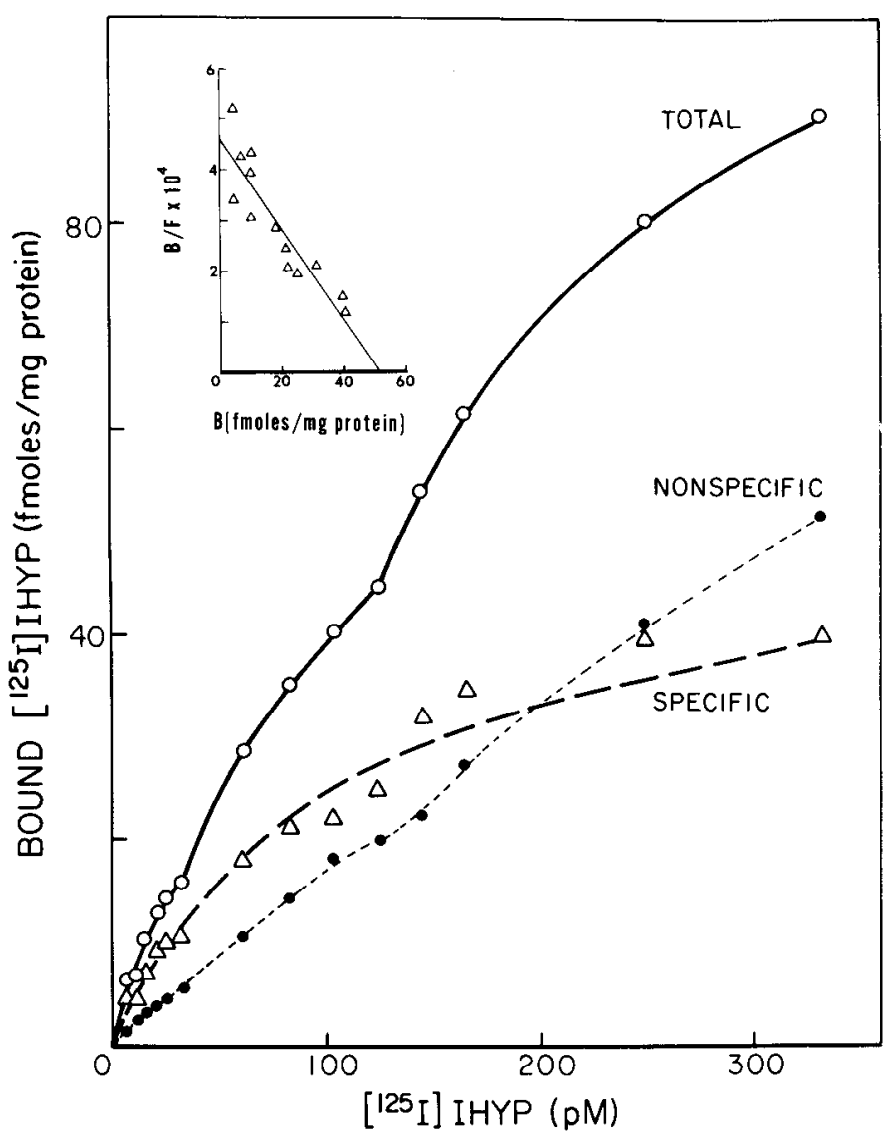

Figure 2. tquilibrium binding of $\mathrm{l}^{125} \mid \mathrm{H} \mathrm{HY}$ to $\mathrm{LRM} b \mathrm{~S}$ cells as a function of ligand concentration. Crude cell preparations ( $100 \mu \mathrm{g}$ of protein/tube) were incubated for $60 \mathrm{~min}$ at $37^{\circ} \mathrm{C}$ with various concentrations of $\left.\left[{ }^{125}\right]\right] \mathrm{HYP}$. Specific binding $(\triangle)$ is the difference between total $(O)$ and nonspecific $(\Theta$ binding. Inset, Scatchard plot of equilibrium binding data.

ments of binding, CAMP, and taurine release, respectively. Cells were fed modified Ham's F-12 medium (Vogel et al. 1972), supplemented with $3.5 \%$ fetal calf serum. Experiments measuring CAMP stimulation and taurine release were performed on monolayers of cells. For binding assays cells were washed three times with $1 \mathrm{ml}$ of HEPES-buffered Hanks' saline $(\mathrm{HH}), \mathrm{pH} 7.3$, scraped off the plates, and gently homogenized in $\mathrm{HH}$ with a loose-fitting Dounce homogenizer. Light microscopic observation of this suspension revealed a mixture of whole cells and membrane fragments.

Binding assays. Agonists, antagonists, and [25]]HYYP solutions were prepared in $\mathrm{HH}$ containing $0.5 \mathrm{~mm}$ ascorbate $(\mathrm{HHA})$ as the binding medium. The binding method used was a modified version of that described by Maguire et al. (1976a). Homogenates were added to glass or polypropylene tubes in 100- $\mu$ laliquots. Binding medium (supplemented with test compounds when needed) was added in $250-\mu$ l portions, and binding was started by addition of $250 \mu \mathrm{l}$ of [ $\left.\left.{ }^{125}\right]\right] \mathrm{HYY}$. The tubes were vortexed immediately and incubated at $37^{\circ} \mathrm{C}$ in a temperature-controlled water bath. Binding was terminated by adding $5 \mathrm{ml}$ of $\mathrm{HH}$ to each tube. The tube contents were immediately filtered on Whatman (Clifton, NJ) GF/A glass-fiber filters with a filtration manifold (Hoeffer Scientific Instruments, San Francisco, CA). Filters were washed four times with $9 \mathrm{ml}$ of $\mathrm{HH}$ and counted in a scintillation counter (Beckman Instruments, Irvine, CA).

Total and nonspecific binding were determined as binding of $\left[{ }^{125} \mid\right] \mid \mathrm{HYP}$ in the absence and presence, respectively, of $10^{-6} \mathrm{M}(-)$-PROP. All incubations were performed in duplicate unless otherwise specified. Specific binding was calculated as the difference between total and nonspecific binding.

$K_{\mathrm{m}}$ and $B_{\max }$ values were obtained from equilibrium binding studies by analysis with the LIGAND program (Munson and Rodbard, 1980) as modified by M. H. Teicher (MED-58, Biomedical Computing Technology Information Center, Vanderbilt University, Nashville, TN)

CAMP accumulation. IPR and other drugs to be tested for CAMP stimulation were dissolved in HHA. All stimulation experiments were performed at $37^{\circ} \mathrm{C}$. Monolayers of cells were washed three times with 1 -mi portions of $\mathrm{HH}$ exposed to $250 \mu$ l of IPR (or combination of drugs) for exactly $1 \mathrm{~min}$ (or specified time). The incubation mixture was aspirated and replaced by 400 $\mu \mathrm{l}$ of $6 \%$ trichloroacetic acid (TCA). One hundred microliters of tritiated cAMP recovery marker were added to each well and the contents were sonicated and transferred to a centrifuge tube. Each well was washed with two additional $250-\mu \mathrm{l}$ portions of TCA, and the TCA precipitate was separated from the supernatant by centrifugation. The TCA supernatant $(500 \mu l)$ was then extracted three times with water-saturated ether, the ether phase was discarded, and the water phase was evaporated to dryness and tested for CAMP content after reconstitution in sodium acetate buffer according to kit instructions. Protein contents were determined on total cells per well dissolved in $0.4 \mathrm{~N} \mathrm{NaOH}$. Protein and cAMP measurements were performed on triplicate wells.

Taurine release. Release of taurine was measured as described previously (Shain and Martin, 1984). Incubations and perfusions were carried out in HHA. In a typical experiment, cells grown on a cell support film were incubated with $\left[{ }^{3} \mathrm{H}\right]$ taurine $(10 \mu \mathrm{Ci} / \mathrm{ml}$ of $\mathrm{HHA})$ for $60 \mathrm{~min}$, mounted in glass columns, and perfused with HHA initially and between drug applications. IPR or other drugs were applied for $3 \mathrm{~min}$. One-minute $(0.5 \mathrm{ml})$ fractions were 
Figure 3. Stereoselectivity of [ $\left.\left[{ }^{125}\right]\right] \mathrm{HYP}$ and IPR. Crude cell preparations (90 $\mu \mathrm{g}$ of protein/tube) were incubated for $60 \mathrm{~min}$ at $37^{\circ} \mathrm{C}$ with $\left.50 \mathrm{pM}\left[{ }^{125}\right]\right] \mathrm{HYP}$ in $\mathrm{HHA}$ or in various concentrations of $(-)-P R O P(O)$, $(+)$-PROP (-), (-)-IPR ( $\square$ ), and (+)-IPR (西. The control value was obtained from quadruplicate samples; all others were from duplicate samples. binding inhibition to LRM55 cells by PROP

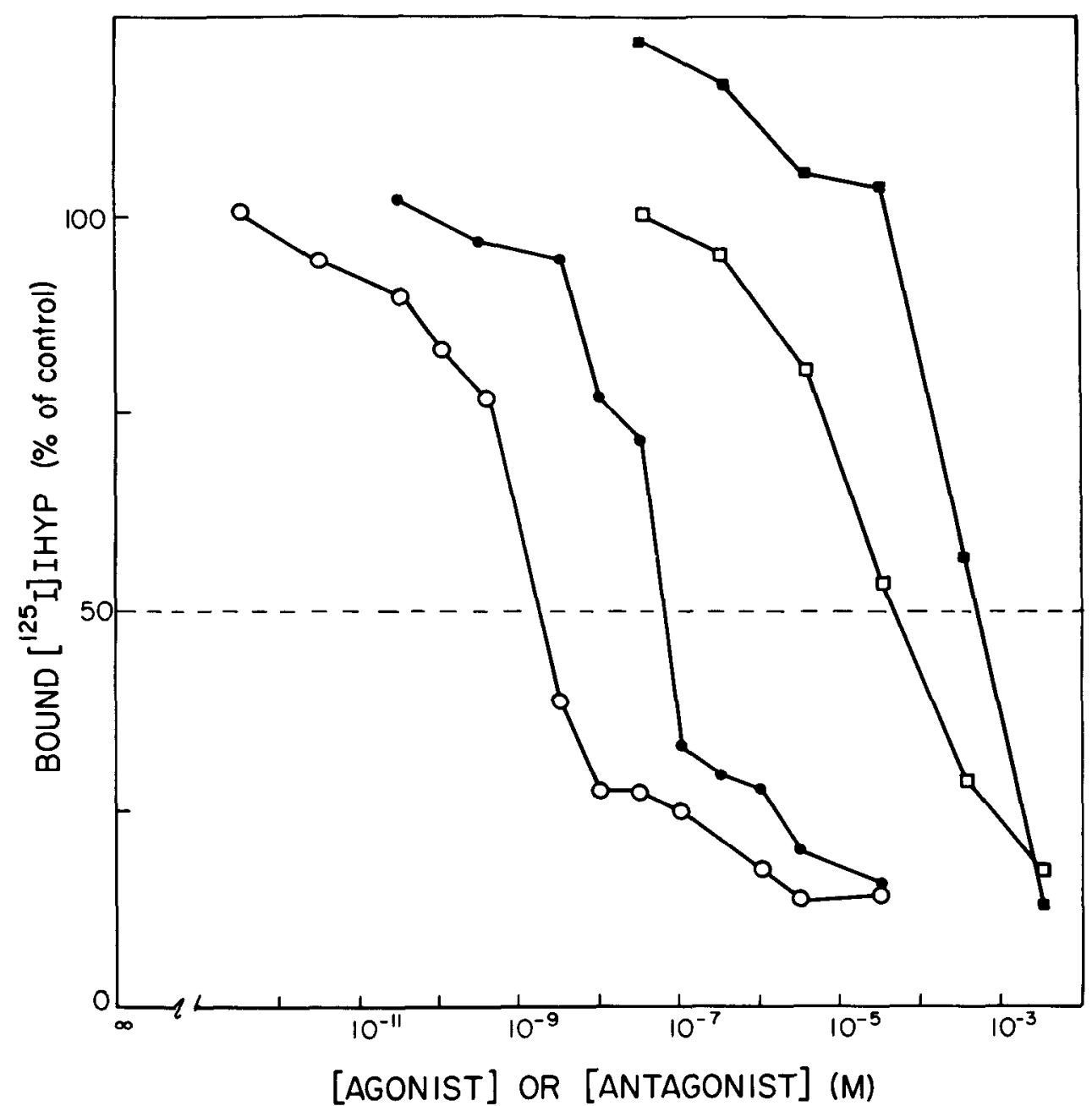

collected throughout and counted for radioactivity. At the end of the run, the strip of cells was removed from the column and used to measure total remaining radioactivity. To normalize values from various perfusions, a $10^{-7}$ M IPR application was included as a point of reference in most experiments.

Protein. Protein concentrations were determined by the dye-binding method (Bradford, 1976) with bovine serum albumin as the standard.

\section{Results}

Kinetics of binding. Specific binding of [ $\left.\left.{ }^{125}\right]\right] \mathrm{HYP}$ to LRM55 cell preparations was dependent on protein concentration, temperature, and ligand concentration. Within the range tested (10 to $100 \mu \mathrm{g}$ of protein/tube), specific binding increased linearly with increasing protein concentration (data not shown).

Binding was both time and temperature dependent. At $37^{\circ} \mathrm{C}$ and $\left.24 \mathrm{PM}\left[{ }^{125}\right]\right] \mathrm{HYYP}$, total binding rose sharply during the first few minutes, then continued to increase at a reduced rate (Fig. 1). Nonspecific binding also rose sharply during the first few minutes but leveled off around $3 \mathrm{~min}$ and remained constant throughout the experiment. Under these conditions specific binding reached halfsaturation within $10 \mathrm{~min}$ and 80 to $90 \%$ saturation by $30 \mathrm{~min}$.

Equilibrium binding. As shown in Figure 2, at equilibrium, nonspecific binding increased linearly with increasing ligand concentration, total binding increased nonlinearly, and both appeared to be nonsaturable. Specific binding therefore increased rapidly at first and then reached a plateau near $200 \mathrm{pM}\left[{ }^{125} \mid\right] \mathrm{HYP} . K_{\mathrm{m}}$ and $B_{\max }$ values from these equilibrium studies (Fig. 2, inset) were $113 \mathrm{pm}$ and 52.1 $\pm 5.0 \mathrm{fmol} / \mathrm{mg}$ of protein, respectively.

Stereoselectivity of binding. Competition studies between $\left[{ }^{125} \mid\right]$ IHYP and stereoisomers of the $\beta$-adrenergic agonist IPR and antag- onist PROP were performed to determine their relative potency and stereoselectivity of binding inhibition. Both IPR and PROP inhibited $\left.\left[{ }^{125}\right]\right] \mathrm{HYP}$ binding to cell preparations (Fig. 3). As expected, the $\beta$ antagonist PROP was a much more potent inhibitor than the $\beta$ agonist IPR. Both compounds showed marked stereoselectivity with the $(-)$-isomers 10 to 50 times more potent than their $(+)$-counterparts.

CAMP accumulation. In order to prevent degradation of cAMP formed due to phosphodiesterase (PDE) acivity, stimulation studies of CAMP are frequently performed in the presence of a PDE inhibitor. Thus, the intracellular accumulation of CAMP was followed as a function of time of exposure to IPR in the absence and presence of the PDE inhibitor RO 20-1724 (Fig. 4). The time course is characterized by a sharp rise during the first few minutes of exposure to agonist followed by a gentle decline to a new level appreciably higher than the base line. The presence of RO 20-1724 in the incubation mix resulted in greater accumulation of cAMP even at early times, and this effect became more pronounced at later times (Fig. 4 , inset). However, since inclusion of the PDE inhibitor was not necessary to detect measurable amounts of CAMP, RO-1724 was omitted from routine experiments to parallel conditions used for taurine release. Standard assays used 1-min exposure times.

Taurine release. When LRM55 glial cells were exposed to IPR, there was a time- and dose-dependent release of taurine. Figure 5 shows a series of release profiles with increasing times of exposure to $10^{-7} \mathrm{M}$ IPR. It is clear that the peaks broaden and eventually develop a distinct shoulder as exposure time is increased. The relationship between length of exposure period and stimulated taurine release is linear from 1 to $10 \mathrm{~min}$, but with longer application 
periods there is an attenuation of taurine release (Fig. 5, inset). Because the present studies focus on the activation of taurine release, a 3-min exposure to IPR was used for routine assays.

Comparison of time courses of CAMP accumulation and taurine release. Since $\beta$-adrenergic stimulation of LRM55 cells results in increased CAMP accumulation and release of taurine, parallel experiments were designed to measure the intracellular accumulation of CAMP and the rate of taurine release at specific times after application of $10^{-7} \mathrm{M}$ IPR. These time courses are remarkably similar (Fig. 6): they bolh rise rapidly in response to IPR stimulation, reach a maximum by 2 to $3 \mathrm{~min}$, and decline thereafter. The rate of decline for release appears to be greater than that for the decline of intracellular CAMP.

Pharmacology. Three adrenergic agonists (IPR, NE, and E) were compared in experiments designed to describe the pharmacology of (a) receptor occupancy as measured by specific [ $\left.\left.{ }^{125}\right]\right] \mathrm{HHYP}$ binding, (b) adenylate cyclase activation as measured by increases in intracellular accumulation of CAMP, and (c) taurine release (Fig. 7). Of these, IPR was the most potent inhibitor of [ [ $\left.\left.{ }^{125}\right]\right] \mathrm{HYY}$ binding and stimulation of CAMP accumulation and taurine release. NE and $E$ were about equipotent as inhibitors of $\left.\left[{ }^{125}\right]\right] \mathrm{HYP}$ binding (Fig. $7 \mathrm{~A}$ ) and stimulators of taurine release (Fig. $7 \mathrm{C}$ ); however, $\mathrm{E}$ was significantly more potent in stimulating CAMP accumulation than was NE (Fig. 7B). The high potency of IPR is expected of $\beta$ - but not $\alpha$ adronergic receptors (Lands et al., 1967).

The $\beta$-adrenergic nature of these receptors was further demonstrated by comparing the effect of two $\beta$-antagonists, ALP and PROP, and the $\alpha$-antagonist PHENT on specific [ $\left.{ }^{125} \mid\right] \mid \mathrm{HYP}$ binding, cAMP contents, and taurine release. The two $\beta$-antagonists were

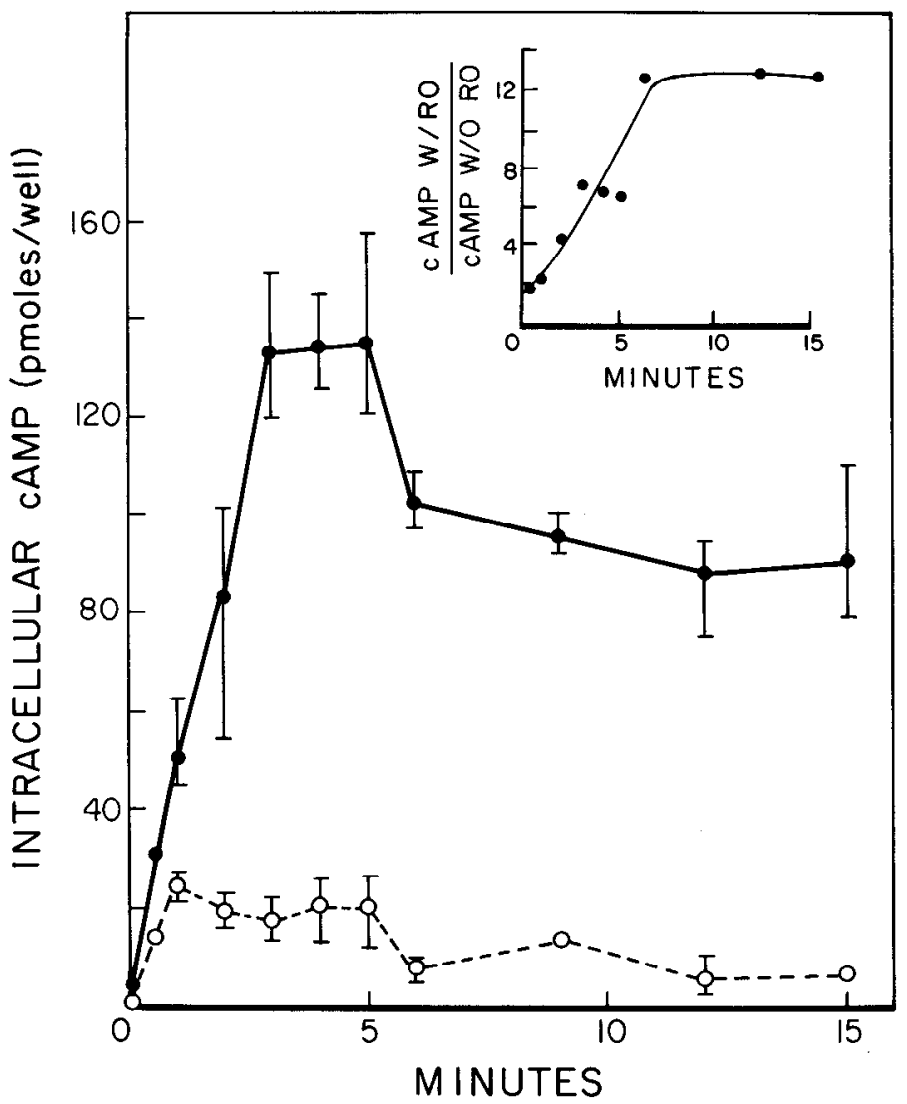

Figure 4. Time course of IPR-stimulated intracellular cAMP accumulation in the presence and absence of RO 20-1724. Monolayers of cells (43 $\mu \mathrm{g}$ of protein/well) were treated with $10^{-7} \mathrm{M} I P R / H H A$ alone $(\mathrm{O})$ or in the presence of $10^{-4} \mathrm{M}$ RO 20-1724 (O) for increasing periods of time and the intracellular cAMP concentrations measured as described under "Materials and Methods." Inset, The ratio of intracellular cAMP concentrations in the presence and absenco of RO 201724 expressed for each time point.

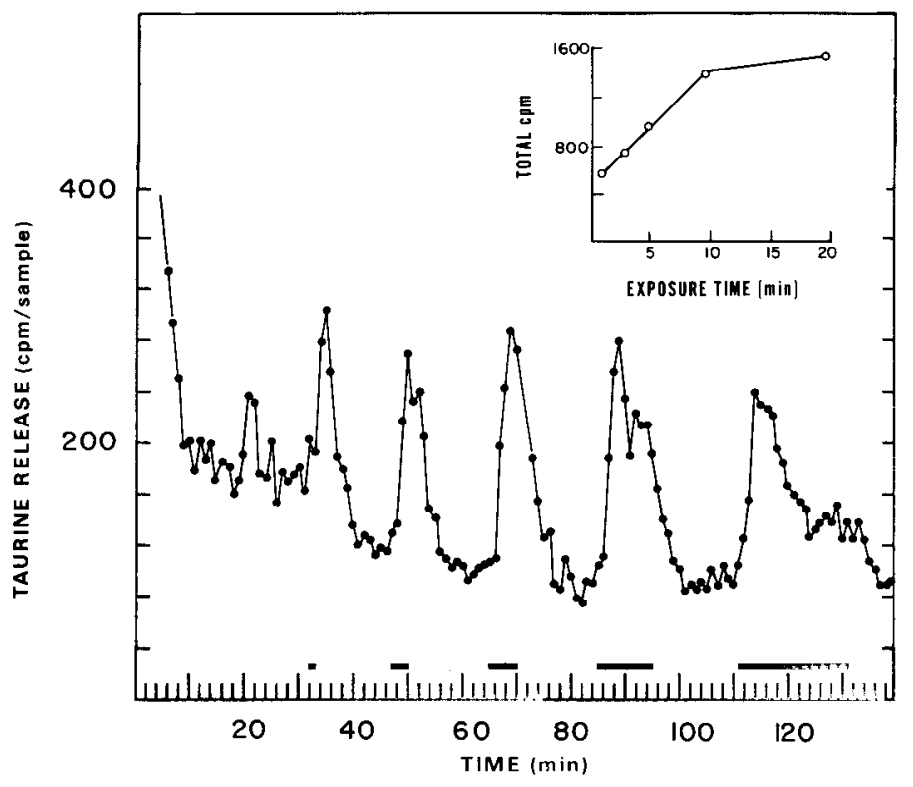

Figure 5. Effect of IPR application time on total amount of $\left[{ }^{3} \mathrm{H}\right]$ taurine release. Pieces of cell support film with cells grown to confluence were incubated 60 min with $\left[{ }^{3} \mathrm{H}\right]$ taurine, transferred to the perfusion chamber, and perfused, first with $\mathrm{HH}$ buffer, then with $10^{-7} \mathrm{M}$ IPR for increasing periods of time (bars). A-15 min buffer wash separated drug applications. One-minute $(0.5 \mathrm{ml})$ fractions were collected and the radioactivity in each vial was determined by liquid scintillation counting. Inset, Total release (calculated by summing the radioactivity in the samples in each peak above the estimated base line) expressed as a function of IPR application time.

nearly equally potent in all three receptor measures. The concentrations of PROP and ALP required to inhibit $50 \%$ of each set were $\leq$ $3 \times 10^{-8} \mathrm{M}$. The $\alpha$-antagonist PHENT was ineffective at these concentrations $\left(\mathrm{EC}_{50} \geq 5 \times 10^{-6} \mathrm{M}\right)$.

A comparison of the $\mathrm{EC}_{50}$ values derived from Figures 7 and 8 (see Table I) can be used to make the following obervations on the relationship of receptor-mediated CAMP accumulation and taurine release. (1) $\mathrm{EC}_{50}$ values for agonists are greater for cAMP accumulation than for taurine release, indicating that taurine release is a more sensitive measure of $\beta$-receptor stimulation of adenylate cyclase activation than is measurement of intracellular CAMP. A small amount of CAMP accumulation may be sufficient to stimulate taurine release, resulting in a shift in the release dose response curve to the left. (2) $I C_{50}$ values for antagonists are nearly identical for receptormediated cAMP accumulation and taurine release. Since $\mathrm{IC}_{50}$ values for PROP, ALP, and PHENT are measures of the competition between the antagonists and the agonist IPR for receptor-binding sites, the similar $\mathbb{I C}_{50}$ values for cAMP accumulation and taurine releases indicate that the same population of receptors is involved with both cellular responses.

These observations and the similarity of the cAMP and taurine release time courses are consistent with the hypothesis that there is a causal relationship between these two events. To directly test this hypothesis, membrane-permeable, nonhydrolyzable analogues of cAMP were used as potential secretagogues. Application of $\mathrm{db}$ cAMP resulted in a dose-dependent increase in taurine release (Fig. 9), with a maximal effect at $10^{-3} \mathrm{M}$. Similarly, 8-Br-cAMP also stimulated taurine release (data not shown).

\section{Discussion}

Receptors on LRM55 cells characterized in the present study by $\left[{ }^{125} \mid\right] \mid \mathrm{HYP}$ binding are similar in kinetic and pharmacological properties to $\beta$-receptors described in other glial preparations. Specific binding of [ $\left.{ }^{125} \mid\right] \mid \mathrm{HYP}$ in LRM55 ceils is saturable with time and ligand concentration. The calculated $K_{m}$ of $113 \mathrm{pM}$ is similar to other reported values: $50 \mathrm{pm}$ (Terasaki and Brooker, 1978) to $140 \mathrm{pm}$ 


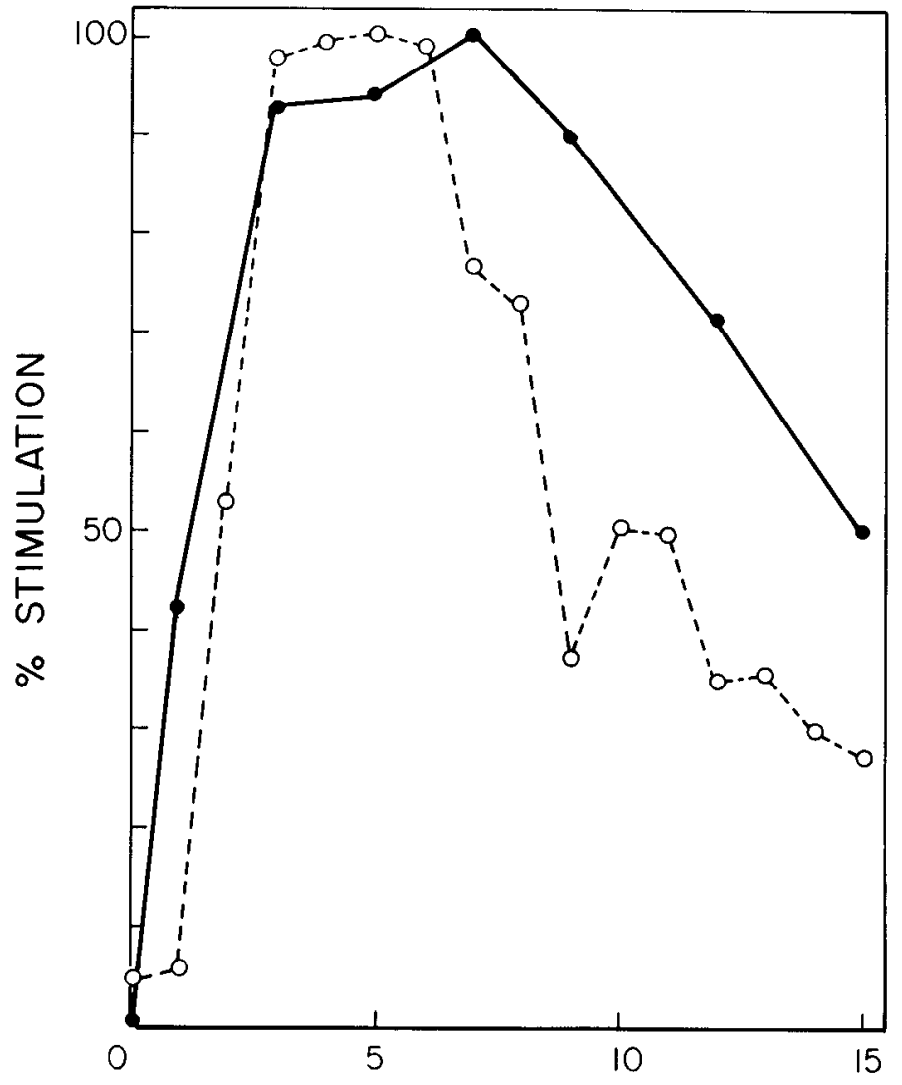

MINUTES

Figure 6. Time courses of IPR-stimulated CAMP accumulation and taurine release. Cells $(50 \mu \mathrm{g}$ of protein/well) grown in 24 -well dishes were washed and exposed to $10^{-7} \mathrm{M}$ IPR for the indicated lengths of time. cAMP concentrations (-) were measured as described previously and expressed as a percentage of the maximal value obtained. For taurine release $(O)$, cells on support film were mounted in the perfusion chamber, washed with buffer, and exposed to $10^{-7} \mathrm{M} I \mathrm{PR}$ continuously for $15 \mathrm{~min}$. One-minute $0.5 \mathrm{ml}$ fractions were collected and counted for radioactivity; release is expressed as percentage of the maximal value obtained.

(Schmitt and Pochet, 1977) for intact C6 cells, and 250 pM (Maguire et al., 1976a) for C6 membrane preparations. For human astrocytes (Johnson et al., 1978) the reported $K_{\mathrm{D}}$ is $73 \mathrm{pM}$. The calculated $B_{\max }$ for LRM55 cells is $52.1 \pm 5.0 \mathrm{fmol} / \mathrm{mg}$ of protein (5600 sites/cell). Similar amounts of binding have been reported for other glial cells. For the C6 cell line binding ranges from $75 \mathrm{fmol} / \mathrm{mg}$ of protein, or 4000 sites/cell (Maguire et al., 1976b), to 7000 sites/cell (Schmitt and Pochet, 1977), or approximately $131 \mathrm{fmol} / \mathrm{mg}$ of protein (assuming $10^{7}$ cells $=1 \mathrm{mg}$ of protein). The $B_{\max }$ reported for human astrocytcs is $186 \mathrm{fmol} / \mathrm{mg}$ of protein (Johnson et al., 1978). [ [25] IHYP binding to LRM55 cells is also highly stereoselective. The rank order of specific binding inhibition by agonists (IPR $>E \geq N E$ ) and antagonists (ALP and PROP $\gg$ PHENT) is characteristic of a $\beta$-type system.

Stimulation of LRM55 cells by IPR, NE, and $E$ results in elevated levels of intracellular cAMP. Since Gilman and Nirenberg (1971) first demonstrated an elevation of intracellular cAMP in three glial cell lines after stimulation by NE and IPR, cyclase activation has been extensively studied in glia (references above; Browning et al., 1976; Franklin and Twose, 1976; McCarthy and deVellis, 1978; Su et al., 1979; Moylan et al., 1982). The pharmacology of agonist-stimulated CAMP accumulation and the inhibition pattern of the antagonists show a $\beta$-pattern consistent with the $\left[{ }^{125} \mid\right] \mid \mathrm{HYP}$ binding results.

Taurine release from LRM55 cells is also stimulated by IPR, NE, and $E$. The rank order of potency of these agonists (IPR $>E \geq N E$ ) indicates that release is the result of $\beta$-stimulation. Additional evidence that this stimulation occurs via $\beta$-receptor activation is provided by antagonist pharmacology. ALP and pROP, $\beta$-antagonists, effectively inhibit IPR-stimulated taurine release, but the $\alpha$-antagonist

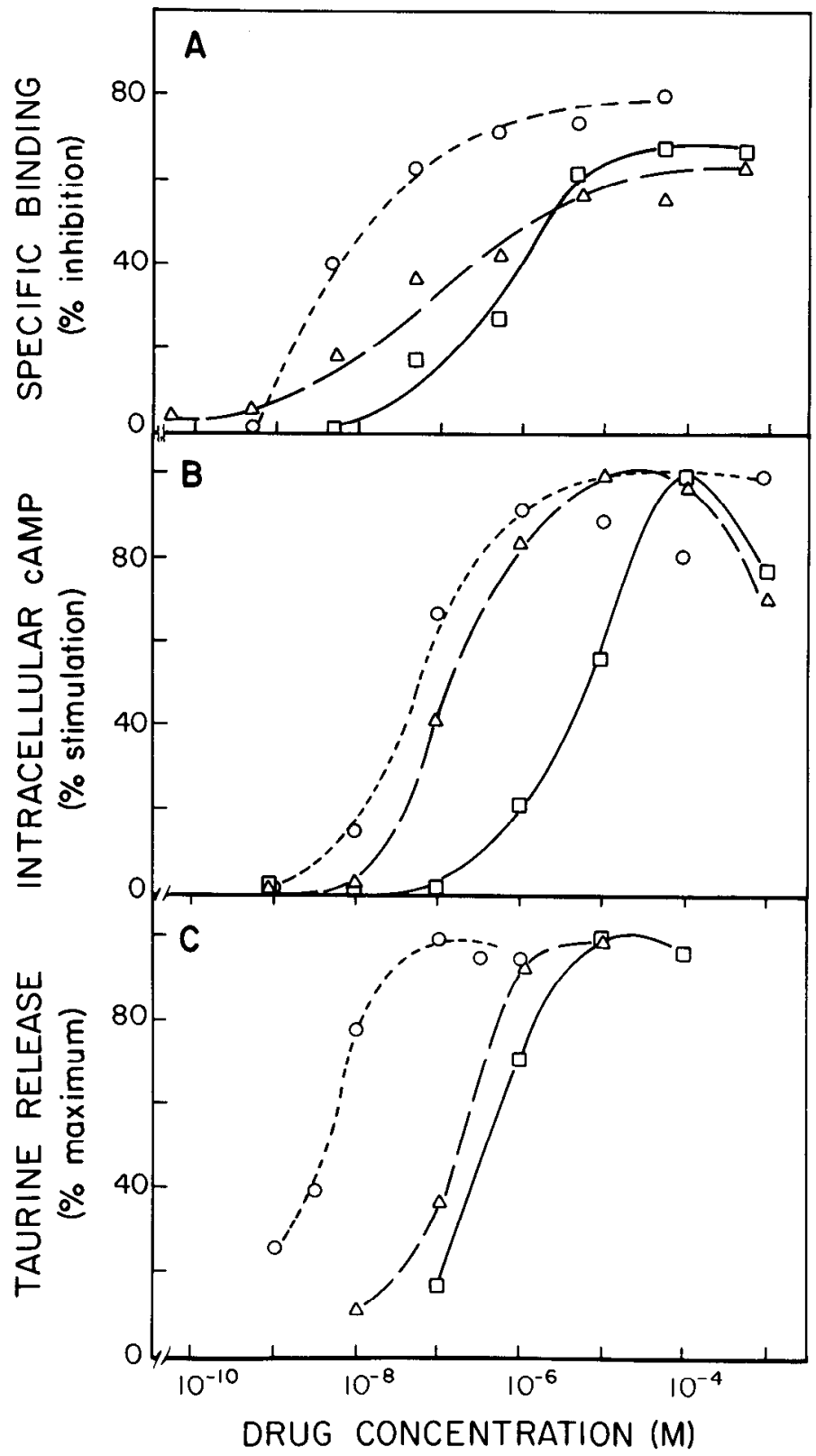

Figure 7. Effect of agonists on specific $\left.\left[{ }^{125}\right]\right]$ HYP binding $(A)$, CAMP accumulation $(B)$, and taurine release $(C)$. $A$, Crude cell preparations $(100$ $\mu \mathrm{g}$ of protein/tube) were incubated $15 \mathrm{~min}$ at $37^{\circ} \mathrm{C}$ with $\left.50 \mathrm{pM}\left[{ }^{125}\right]\right] \mathrm{HYP}$ and various concentrations of agonists in $\mathrm{HHA}$ (total binding) or $10^{-6} \mathrm{M}(-)$-PROP (nonspecific binding). Specific binding values were obtained by subtracting nonspecific from total binding values and were expressed as percentage inhibition of control (control values were obtained from binding in the absence of agonist). $B$, Monolayers of cells ( $41 \mu \mathrm{g}$ of protein/well) were treated with various concentrations of agonists for $1 \mathrm{~min}$ at $37^{\circ} \mathrm{C}$; intracellular CAMP concentrations were measured as previously described and expressed as percentage of maximum cAMP concentration obtained for each agonist. $C$, Cells grown on cell support film and mounted in the perfusion chamber were perfused for 3 min each with increasing concentrations of agonists followed by 17-min washes with HHA. Total taurine released by each agonist concentration was measured as the total radioactivity under each peak and was expressed as percentage of maximum release for each agonist. $O$, IPR; $\triangle$, $E ; \square, N E$. 


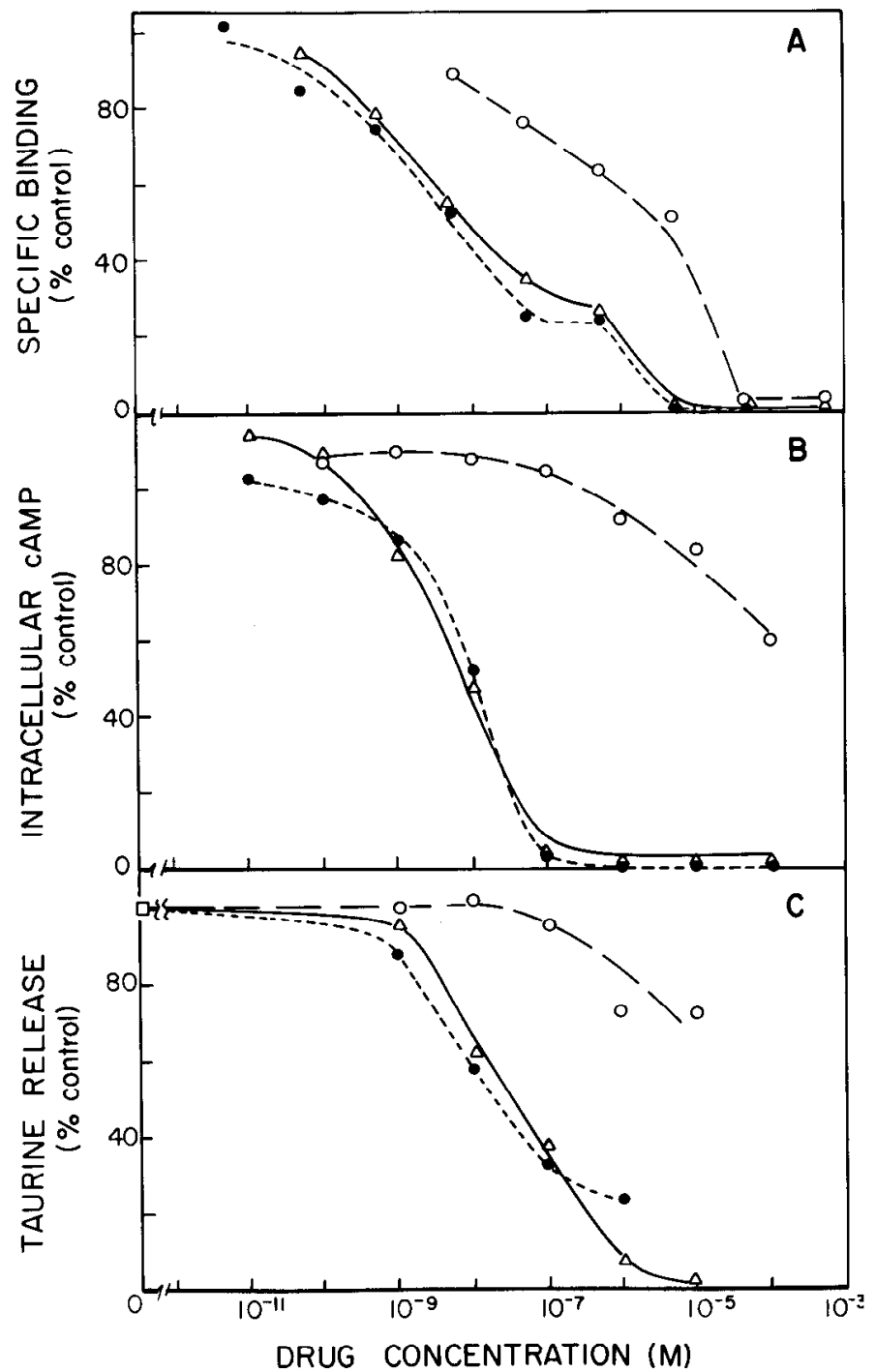

Figure 8. Effect of antagonists on specific [ $\left.{ }^{125}\right]$ IHYP binding $(A)$, IPRstimulated cAMP accumulation $(B)$, and IPR-stimulated taurine release $(C)$. $A$. Crude cell preparations ( $100 \mu \mathrm{g} /$ tube) were incubated $15 \mathrm{~min}$ at $37^{\circ} \mathrm{C}$ with $\left.50 \mathrm{pM}\left[{ }^{125}\right]\right] \mathrm{HYP}$ and various concentration of antagonists in $\mathrm{HHA}$ or $10^{-6} \mathrm{M}(-)$-PROF. Specific binding values expressed as percentage of control were calculated as described for Figure $7 A$. B. Monolayers of cells $(41 \mu \mathrm{g}$ of protein/well) were treated with a mixture of $10^{-7} \mathrm{M}$ IPR and various concentrations of antagonists for $1 \mathrm{~min}$ at $37^{\circ} \mathrm{C}$. Values of intracellular CAMP were obtained and expressed as for Figure $7 B$, the $100 \%$ control value being that obtained by $10^{-7} \mathrm{M} I \mathrm{PR}$ stimulation in the absence of other drugs. $C$, Cells grown on support film and mounted in the perfusion chamber were exposed to $10^{-7} \mathrm{M}$ IPR first (control), then to a mixture of $10^{-7} \mathrm{M}$ IPR and various concentrations of antagonists for $3 \mathrm{~min}$, followed by 17 -min buffer washes. Total taurine release for each drug concentration was measured as in Figure $7 \mathrm{C}$ and expressed as percentage of $10^{-7} \mathrm{M}$ IPR control. PROP; $\triangle$, ALP: O, PHENT.

PHENT does not. Thus, the pharmacology of taurine release is similar to that of CAMP accumulation, consistent with the hypothesis that CAMP may be involved in $\beta$-stimulated taurine release.

Two additional observations are consistent with this hypothesis. First, the onset of IPR-stimulated CAMP accumulation and taurine release show remarkable similarity in their time courses. Second, db-cAMP, a membrane-permeable and nonhydrolyzable analogue of CAMP, stimulates release similarly to $\beta$-agonists. The evidence presented in this study supports the following sequence of events as a rcsult of $\beta$ adrenergic stimulation of the LRM55 glial cells: (a)
TABLE ।

Effect of agonists and antagonists on $\Gamma^{25} / 7 / \mathrm{HYP}$ binding, CAMP accumulation, and taurine release in LRM55 glial cells ${ }^{a}$

\begin{tabular}{|c|c|c|c|}
\hline Agonist & $\left.\left[{ }^{[25}\right]\right] \mathrm{HYP}$ Binding $\left(\mathrm{IC}_{50}\right)$ & $\operatorname{CAMP}\left(E_{50}\right)$ & Taurine Release $\left(\mathrm{EC}_{50}\right)$ \\
\hline & $M$ & M & M \\
\hline IPR & $1.4 \times 10^{-8}$ & $6.0 \times 10^{-8}$ & $4.0 \times 10^{-9}$ \\
\hline $\mathrm{E}$ & $1.0 \times 10^{-6}$ & $1.6 \times 10^{-7}$ & $1.2 \times 10^{-7}$ \\
\hline NE & $2.0 \times 10^{-6}$ & $6.0 \times 10^{-6}$ & $4.0 \times 10^{-7}$ \\
\hline \multirow[t]{2}{*}{ Antagonist } & $\left.{ }^{\lceil 2}{ }^{125} \mid\right] \mathrm{HYP}$ Binding $\left(\mathrm{IC}_{50}\right)$ & CAMP $\left(I C_{50}\right)$ & Taurine Release $\left(\mathrm{IC}_{50}\right)$ \\
\hline & $M$ & $M$ & M \\
\hline PROP & $6.0 \times 10^{-9}$ & $1.0 \times 10^{-8}$ & $2.0 \times 10^{-8}$ \\
\hline ALP & $8.0 \times 10^{-9}$ & $1.0 \times 10^{-8}$ & $3.0 \times 10^{-8}$ \\
\hline PHENT & $5.0 \times 10^{-6}$ & $>10^{-4}$ & $>10^{-4}$ \\
\hline
\end{tabular}

a Summarized from data in Figures 7 and 8.

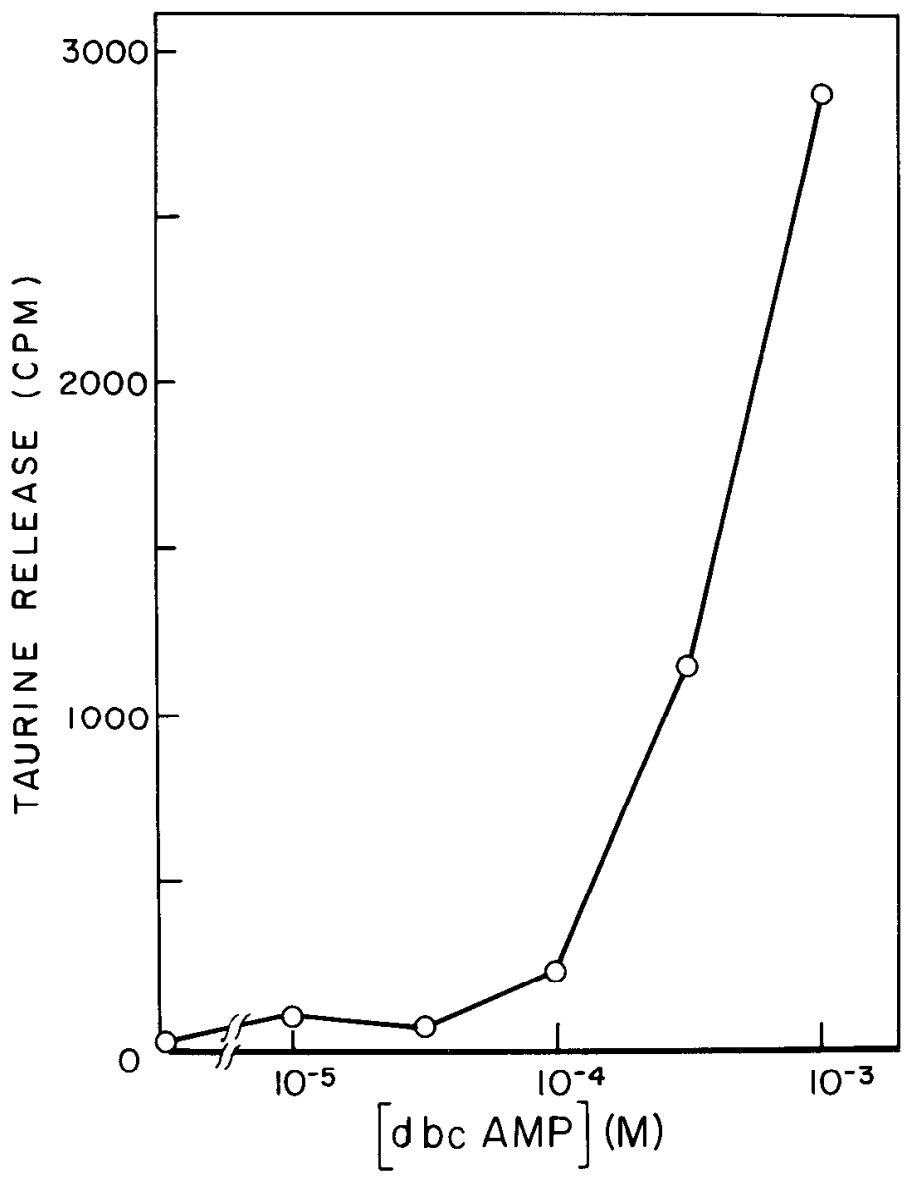

Figure 9. Effect of db-cAMP on taurine release. Cells grown on support film were incubated with $\left[{ }^{3} H\right]$ taurine, mounted in the perfusion chamber, and perfused with increasing concentrations of $\mathrm{db}$-cAMP for 3-min periods. Oneminute $(0.5 \mathrm{ml})$ fractions were collected, and total taurine released by each db-cAMP application is expressed as counts per minute.

receptor occupancy, (b) elevation of intracellular CAMP levels, and (c) release of taurine.

Taurine can be found in high concentration in the brain and causes increased $\mathrm{Cl}^{-}$permeability when applied to neurons (Okamoto et al., 1983). Thus, taurine might be an important inhibitory neuroregulator. Our results with LRM55 glial cells and primary cultures (Shain and Martin, 1984) demonstrate that receptor-mediated taurine release is a glial cell function. Glia can therefore respond to neuronal transmitters by releasing taurine and thereby regulate neuronal activity. 


\section{References}

Banker, G. A. (1980) Trophic interactions between astroglial cells and hippocampal neurons in culture. Science 209: 809-810.

Bowman, C., and H. K. Kimelberg (1984) Glutamate receptors on astrocytes produce depolarizing responses. Nature 311:656-659.

Bradford, M. M. (1976) A rapid and sensitive method for the quantitation of microgram quantities of protein utilizing the principle of protein-dye binding. Anal. Biochem. 72: 248-254.

Browning, E. T., C. O. Brostrom, and V. E. J. Groppi (1976) Altered adenosine cyclic $3^{\prime}, 5^{\prime}$-monophosphate synthesis and degradation by $\mathrm{C} 6$ astrocytoma cells following prolonged exposure to norepinephrine. Mol. Pharmacol. 12: 32-40.

Denis-Donini, S., J. Glowinski, and A. Prochiantz (1984) Glia heterogeniety may define the 3-dimensional shape of mouse mesencephalic dopaminergic neurons. Nature 307: 641-643.

deVellis, J., and G. Brooker (1972) Effect of catecholamines on cultured glial cells: Correlation between cAMP levels and lactic dehydrogenase induction. Fed. Proc. 31: 513.

Franklin, T. J. and P. Q. Twose (1976) Desensitization of $\beta$-adrenergic receptors of glioma cells: Studies with intact and broken cell preparations. FEBS Lett. 66: 225-229.

Gilman, A. G., and M. Nirenberg (1971) Effect of catecholamines on the adenosine $3^{\prime}, 5^{\prime}$-cyclic monophosphate concentrations of clonal satellite cells of neurons. Proc. Natl. Acad. Sci. U. S. A. 68: 2165-2168.

Hatten, M. E., and R. K. H. Liem (1981) Astroglial cells provide a template for the positioning of developing cerebellar neurons in vivo. J. Cell Biol. 90: 622-630.

Hosli, L., E. Hosli, U. Schneider, and W. Wiget (1984) Evidence for the existence of histamine $\mathrm{H} 1$ - and $\mathrm{H} 2$-receptors on astrocytes of cultured rat central nervous system. Neurosci. Lett. 48: 287-291.

Johnson, G. L., B. B. Wolfe, T. K. Harden, P. B. Molinoff, and J. P. Perkins (1978) Role of $\beta$-adrenergic receptors in catecholamine-induced desensitization of adenylate cyclase in human astrocytoma cells. J. Biol. Chem. 253: $1472-1480$.

Kuffler, S. W. (1967) Neuroglial cells: Physiological properties and a potassium mediated effect of neuronal activity on the glial membrane potential. Proc. R. Soc. Lond. (Biol.) 168: 1-21.

Kuffler, S. W., J. G. Nicholls, and R. K. Orkand (1966) Physiological properties of glial cells in the central nervous system of amphibia. J. Neurophysiol. 29: $768-787$

Lands, A. M., A. Arnold, J. P. McAuliff, F. P. Luduena, and T. G. Brown (1967) Differentiation of receptor systems activated by sympathomimetic amines. Nature 214: 597-598.

Maguire, M. E., P. M. Van Arsdale, and A. G. Gilman (1976a) An agonistspecific effect of guanine nucleotides on binding of the $\beta$-adrenergic receptors. Mol. PHarmacol. 12: 335-339.

Maguire, M E., R. A. Wilkund, H. J. Anderson, and A. G. Gilman (1976b) Binding of $\left({ }^{(25}\right)$ iodohydroxybenzylpindolol to putative $\beta$-adrenergic receptors of rat glioma cells and other cell clones. J. Biol. Chem. 251: 12211231.

Martin, D. L., and W. Shain (1979) High affinity transport of taurine and $\beta$ alanine and low affinity transport of $\gamma$-aminobutyric acid by a single transport system in cultured glioma cells. J. Biol. Chem. 254: 7076-7084.

McCarthy, K. D., and J. deVellis (1978) Alpha adrenergic receptor modulation of beta-adrenergic, adenosine and prostaglandin $D_{1}$ increased $3^{\prime}, 5^{\prime}$-cyclic monophosphate levels in primary cultures of glia. J. Cyclic Nucleotide Res. 4: $15-26$.
Morantz, R. A., W. Shain, and H. Cravioto (1978) Immune surveillance and tumors of the nervous system. J. Neurosurg. 49: 84-92.

Moylan, R. D., K. Barovsky, and G. Brooker (1982) N6', O2'-Dibutyryl cyclic AMP and cholera toxin-induced $\beta$-adrenergic receptor loss in cultured cells. J. Biol. Chem. 257: 4947-1950.

Munson, P. J., and D. Rodbard (1980) LIGAND: A versatile computerized approach for characterization of ligand-binding systems. Anal. Biochem. 107: 220-229.

Okamoto, K., H. Kimura, and Y. Sakai (1983) lonic mechanisms of the action of taurine on cerebellar Purkinje cell dendrites in vitro: Intradendritic study. Brain Res. 260: 261-269.

Opler, L. A., and M. H. Makman (1972) Mediation by cyclic AMP of hormonestimulated glycogenolysis in cultured rat astrocytoma cells. Biochem. Biophys. Res. Commun. 46: 1140-1145.

Perrone, M. H., R. E. Diehl, and W. Shain (1983) Identification of putative 3Hsubstance $P$ receptors in LRM55 glial cells. J. Cell. Biol. 97: 245a.

Pope, A. (1978) Neuroglia: Quantitative aspects. In Dynamic Propertie of Glia Cells, E. Schoeffeniels, G. Frank., L. Hertz, and D. B. Towers, eds., pp. 13-20, Pergamon Press, Oxford.

Repke, H., and K. Maderspach (1982) Muscarinic acetylcholine receptors on cultured glia ceils. Brain Res. 232: 206-211.

Rougon, G., M. Noble, and A. Mudge (1983) Neuropeptides modulate the beta-adrenergic response of purified astrocytes in vitro. Nature 305: 715717

Sakazaki, Y., T. Kato, H. Kato, N. Naganawa, T. Kato, R. Tanaka, A. Masaoka, and $H$. Tsunooka (1982) Biological activity of neuroblastoma growth inhibitory factor (NGIF). Proc. Jpn. Cancer Assoc. 41: 425.

Schmitt, $H_{\text {., }}$ and $\mathrm{R}$. Pochet (1977) In vivo labeling of $\beta$-adrenergic receptors on rat glioma cells. FEBS Lett. 76: 302-305.

Seligmann, B., W. Shain, and D. L. Martin (1979) Membrane potential and taurine transport in a cultured glioma cell line. Soc. Neurosci. Abstr. 5: 1021

Shain, W., K. L. Smith, and D. L. Martin (1983) Receptor stimulated release of taurine by glial cells in culture. J. Cell Biol. 97: 244a.

Shain, W., J. A. Greenhouse, V. Madelian, M. Perrone, and R. Lepore (1984) Effects of nociceptive neuropeptides on taurine release from glia. Soc. Neurosci. Abstr. 10: 765.

Shain, W. G., and D. L. Martin (1984) Activation of $\beta$-adrenergic receptors stimulates taurine release from glial cells. Cell. Mol. Neurobiol. 4: 191-196.

Su, U. F. T. K. Harden, and J. P. Perkins (1979) Isoproterenol-induced desensitization of adenylate cyclase in human astrocytoma cells. J. Biol. Chem. 254: 38-41.

Tardy, M., M. F. D. Costa, C. Fages, J. Bardakdjian, and P. Gonnard (1982) Uptake and binding of serotonin by primary cultures of mouse astrocytes. Dev. Neurosci. 5: 19-26.

Teresaki, W. L., and G. Brooker (1978) $\left({ }^{125}\right)$ lodohydroxybenzylpindolol binding sites on intact rat glioma. J. Biol Chem. 253: 5418-5428.

Van Calker, D., and B. Hamprecht (1980) Effects of neurohormones on glial cells. Adv. Cell. Neurobiol. 1: 31-67.

Varon, S., and G. G. Somjen (1979) Neuron-glia interactions. Neurosci. Res. Program Bull. 17: 1-239.

Vogel, Z., A. J. Sytkowski, and M. W. Nirenberg (1972) Acetylcholine recepors of muscle grown in vitro. Proc. Natt. Acad. Sci. U. S. A. 69: $3180-3184$.

Waniewski, R. E., and D. L. Martin (1983) Selective inhibition of glial versus neuronal uptake of L-glutamic acid by SIIS. Brain Res. 263: 390-394.

Wolpaw, E., D. L. Martin (1982) Chloride transport in glioma cells. Trans. Am. Soc. Neurochem. 13: 134 